\title{
Virtual Warfare: Masculinity, Sexuality, and Propaganda in the Russo-Ukrainian War
}

\author{
Maryna Romanets \\ University of Northern British Columbia
}

\begin{abstract}
This paper explores the intersection of sexual and political discourses as a particular aspect of the body politics that Russia has employed, among other strategies, in its massive propaganda offensive during the hybrid warfare against Ukraine. While recognizing sexuality as one of the mainstream concepts in political analysis, the paper draws on sexually explicit imagery and idiom used in Russian social media, and public discursive space in general, as propaganda techniques, and maps their "genealogy" within wider sociocultural and political contexts. Being conceptualized in terms of Russian hegemonic masculinity in relation to subordinated femininity and non-hegemonic masculinities of its adversarial others, these setups reveal how sexuality constitutes uneven and contradictory nexuses of power once being co-opted by Putin's propaganda machine. It is noteworthy that Russia's neo-imperial discursive tactics of homologizing sexual and political dominance-when supplemented with the official rhetoric of restituting Russia as a great power, Orthodox Christian fundamentalism as an integral part of Russian unique "state-civilization," state-sanctioned homophobia, and traditional macho gender ideology—contribute quite effectively to sustaining public support in Russia for aggression against Ukraine in the process of Russian reimperialization of the former Soviet space.
\end{abstract}

Keywords: propaganda, Russo-Ukrainian war, masculinity, sexuality.

A close-up photograph of a man's austere face, with his mouth stitched shut, staring expressionlessly at the viewer, another one with a naked male figure cocooned in barbed wire. Another photograph shows a naked man with his scrotum nailed to the cobblestones in Moscow's Red Square. These disturbing images of living-pain sculptures created by Petr Pavlenskii, the Russian artist who turns his body into a medium to explore politics, instantly captured the world's attention (see more in Sneider). By literally inserting himself into the politics of his work and thus reflecting the violence of the state through self-mutilating gestures, the artist turns his naked body into a palpable signifier in a country where all reference points seem to disappear into a vortex of the media's hyperreal propaganda, and where "real" comes into being only through the state-sanctioned, strategic dissemination of simulacra that operate all by themselves, without having 
any reference to reality (Baudrillard 166-84). Pavlenskii's actionism ${ }^{1}$ feeds off the increasingly repressive tendencies of Vladimir Putin's third term in office, a term that has shifted in emphasis from "stability" to militant popular mobilization-which "reached a frenzied peak after the annexation of Crimea" (Pratt) - and to "aggressive reimperialization" of the former Soviet space (Van Herpen, Putin's Wars 5, 276). While the artist uses the body to "desecrate" symbolically important spaces and narratives, belligerent official Russia has taken up performance art strategies to undermine the geopolitical order and promote Russia's neo-imperialist ambitions. Russia employs, among others, issues related to the current state body politics in the massive propaganda offensive launched in its hybrid war in Ukraine (Van Herpen, Putin's Propaganda 1-2).

I intend to explore here a particular aspect of the body politics, located at the intersection of sexual and political discourses, by drawing on sexually explicit imagery and idiom used in Russian social media, and public discursive space in general, as propaganda techniques in the current RussoUkrainian war, and to map its "genealogy" within wider sociocultural and political contexts. While recognizing sexuality as one of the mainstream concepts in political analysis, I view it, in the framework of this discussion, as a site for political constructivism and calculated performativity, since the body, according to Michel Foucault, does not stand in an external relation to power but is inscribed by a historically contingent conjunction of power and discourse: "[T] he body is also directly involved in a political field; power relations have an immense hold upon it; they invest it, mark it, train it, torture it, force it to carry tasks, to perform ceremonies, to emit signs" (25). Furthermore, when theorized in postcolonial terms, the body is always "simultaneously (if conflictually) inscribed in both the economy of pleasure and desire and the economy of discourse, domination, and power" (Bhabha 96). Thus, the inquiry into sexualized discourses that operate within the Russo-Ukrainian war, and are conceptualized in terms of hegemonic masculinity in relation to subordinated femininity and non-hegemonic masculinities, is instrumental in revealing how sexuality constitutes nexuses of power while being co-opted by Putin's propaganda machine.

As the point of departure for my analysis, I consulted a Russian Weblibrary that hosts thousands of ready-made offensive images that are largely aimed at debasing Ukrainian (and Western) officials while representing President Putin of Russia as an alpha male of the international arena (Schreck). The images have been used to "add colour" to the propagandistic

\footnotetext{
1 "Actionism is the English version of the general German term for performance art, specifically used for Vienna-based group Wiener Aktionismus, founded in 1962, whose actions were deliberately shocking, often including self-torture" ("Actionism").
} 
comments produced by Russia's "troll army," whose headquarters were recently discovered in St. Petersburg (Walker). Inside this notorious "Russian troll house," hundreds of "firmly instructed," paid bloggers work "round the clock to flood Russian internet forums, social networks, and the comment sections of western publications" with pro-Kremlin political posts, strictly outlined according to "technical tasks" that the trolls receive each morning (Walker). The website, called VSHtabe.Rf (meaning "in the headquarters, Russian Federation"), emphasizes unambiguously its warmongering status and appeals to the organized cult of the Great Patriotic War as an effective system of Russian political symbols and rituals; it was registered in Russia in March 2014, less than two weeks after Russian annexation of the Crimea. Its massive repertoire, subdivided into such sections as de-motivators, memes, and comics, features recurrent homosexual and transvestite scenarios (VSHtabe.Rf). While politicizing same-sex sexual relations and drag-culture codes in the context of the Russian imperial reflex, the creators of these images, on an overall level, bluntly manipulate the concepts of masculinity and sexual deviancy as part of their anti-adversarial rhetoric because domination for a patriarchal culture can only ever be experienced as a form of emasculation. Thus, the project of "re-masculinizing Russia," unavoidably coupled with "demasculinizing" Western democracies as its significant others, seems to coincide chronologically with Putin's appointment as President Iel'tsin's successor, since the 2000s are identified as the starting point in the revamping of Russia's masculinity ethos (see, for example, Riabov and Riabova). ${ }^{2}$ It is also interesting that the sexually charged construct of Putin the Emasculator, quite pervasive in the Russian collective imaginary, also surfaces, rather surprisingly, in the discussion of his repressive strategies among critics of Putin's regime, who state that he reconsolidated Russia by "emasculating" it, "weakening first and emasculating institutions that underlined ... the division of power," and taking "under control Russian governors, by emasculating federalism" (Allawala).

While the homogenized West is the primary target of Russian political ambitions-since Russia as a hypothetically reimperialized superpower aspires to deal with it on par-Ukraine, for Russia and its neo-imperialist president, is "just a place, populated by people who resemble Russians, and not an independent state with a national identity of its own" (Motyl), which is attempting to escape from what Russia considers to be its "legitimate" sphere of interests. Thus, it is subjected to a different kind of emasculation as an inferior object of major players' geopolitical desires, one that draws on

2 I am grateful to one of my anonymous reviewers for making some literature suggestions. 
the discursive strategies of colonizers who, "in what was intended as an insult, often labeled colonized men as effeminate or homosexual" (Sands 5). In her analysis of the homology between sexual and political dominance in imperial discourses, Revathi Krishnaswamy contends that the "goal of feminization is effeminization," a process in which colonizing men use women/womanhood to delegitimize, discredit, and disempower colonized men. Thus, masculinity and sexuality here are turned into a tropological site, where many uneven and contradictory axes of power are simultaneously constituted and contested (Krishnaswamy 3). As Oleg Riabov and Tatiana Riabova point out, in the new millennium

Russian political rhetoric has referred [to] the de-masculinization of Ukraine in terms that make it an integral part of the re-masculinization of Russia. In Putin's rhetoric as well as elsewhere, the former Ukrainian Soviet republic has frequently been represented as a gasping paramour, or flighty mistress cum bride.

Being part of Russian identity politics, such conventional symbolic assimilation of the "indigenous female" into the colonized territory gives credence to the articulation of "colonial control" as a form of "s exual control" (Mitchell 57) by the aggressive, assertive, and masculine colonizer. Although the "gendering of imperialism took very different forms in different parts of the world" (McClintock 31), it was always woman-often "figured as the epitome of sexual aberration and excess" (22) - who was inscribed in gender pattern to "naturalize" imperial dominance.

It is also noteworthy that Russian current discursive strategies borrow explicitly from the storehouse of conventional imperial idiom. Thus, analogously to contemporary Russian representational regimes, nineteenthcentury British imperial masculinity, for example, was defined in terms of a "series of 'others,' namely domination over women, homosexuals and native people," and was characterized by "intense homophobia" during the latter half of the nineteenth century (Beynon 28). Furthermore, it was in the nineteenth century that imperial historical discourses became "highly gendered, resulting in a dichotomy between masculine colonizers and the effeminate colonial subjects" (Freitag 193), since the colonial project relies greatly on homosocial forms of domination. Although centuries-old, these techniques, when supplemented with the official rhetoric of restituting Russia as a great power, feared and respected worldwide, Orthodox Christian fundamentalism as an integral part of Russian unique "statecivilization" (Riabov and Riabova), state-sanctioned homophobia, and traditional macho gender ideology, contribute-quite effectively-to sustaining public support in Russia for aggression against Ukraine.

A number of resource images on VSHtabe. $R$ fare violent-suggestive of same-sex rape-and, in an uncanny way, replicate setups represented in 
Russian Criminal Tattoo Encyclopedia, a compendium of more than three thousand tattoos, many of them sexually explicit, collected over a lifetime by Danzig Baldaev, a prison guard. Cultural and symbolic associations of being penetrated with "feminine" passivity are well-established, as are associations of passivity with the loss of male political and social power. Michelene Wandor writes that in terms of metaphorical signification, the "rape of man by man operates with more resonance than the rape of a woman by a man. The symbolism of sexual violence is here displaced on to homosexuality, and the way it evokes traditional notions of homosexuality as 'unnatural'” (187). Moreover, one should keep in mind that Russian society seems to subscribe predominantly to the eighteenth-century view that homosexuality is a "crime against nature" or to the late nineteenthcentury medical concept that it is a "manifestation of inherited psychological degeneration" (Greenberg 1), as formulated in the pioneering study in sexual psychopathology, Psychopathia Sexualis (1886) by Richard Krafft-Ebing, which forged attitudes toward various sexual "deviations." Medicalized and pathologized, the nineteenth-century male homosexual's composite picture of a "despicable, unacceptable" and "degenerate masculinity" reflected a "pattern of behavior that was in total violation of assumptions about 'normal males"' (Fout 275). Likewise, Russia in the nineteenth century, while adopting "legal measures on sodomy [introduced in the Criminal Code in 1835] and a number of medical documents," also attempted to regulate, control, and establish "normative" sexuality (Stähle 164). Furthermore, since the late nineteenth century "homosexuality has been discursively constructed in Russia within a 'tripartite geography of perversity,'” wherein Russia was situated between a "decadent (homosexual) West and a debauched (homosexual) East," being itself "naturally and purely heterosexual" (Baer 138). It is ironic, however, that the first criminalization of same-sex sexual practices in the military occurred in the early eighteenth century, when "Peter the Great, who often slept with his soldiers, hypocritically made the prohibition secular" as part of his westernization reforms (Greenberg 303). Having been regarded briefly as permissible under liberal legislation in revolutionary Russia, "sodomy was reintroduced to the Soviet Criminal Code in 1934" (Stähle 164). And although it was decriminalized again in 1993, after the collapse of the Soviet Union and as a necessary condition for Russia to become a member of the Council of Europe (Kondakov 161), contemporary Russian proponents of "traditional values" and "spiritual bonds" define themselves, in terms of sexuality, as "naturals" (see, for example, “Geteroseksual'nost'”). While disseminating anti-gay bigotry, they emphasize, as a point of pride, that current Western views on homosexuality as normal are not acceptable in Russia (Sperling 37).

However, it is not only the "masses" in Russia that express profound homophobia, alongside a "range of interlocking social phobias," as reflected 
in sociological research and monitoring (Omel'chenko and Garifzianova 35). A Pew Research Center survey conducted in 39 countries in 2013 revealed that only 16 percent of Russians "say homosexuality should be accepted by society" ("The Global Divide"); the results of the 2015 Russian Levada Center poll showed that " $21 \%$ of Russians want members of the LGBT community 'liquidated,' while $37 \%$ argued that they should be separated from society" (Porter); and the recent state-run VTsIOM poll found that "Russian intolerance of gay people and same-sex marriages has grown significantly in the last decade" (Litvinova, "Poll Shows"). Only 15\% of the poll respondents said homosexuals are "normal people," adding, however, that they "wouldn't socialize with them" (Litvinova, "Poll Shows"). These popular attitudes were reflected in the 1990s campaign against homosexuality that was launched in educational literature, wherein homosexuality was "described as a dangerous pathology and 'an infringement of normal sexual relations'" (Kon 94), and they culminated in today's homophobic legislation. In 2013, Russia's lower house of Parliament (Duma) unanimously adopted a law against the "propaganda of nontraditional sexual relations" (its original wording was much more straightforward-"propaganda of homosexuality" [Komitet]); thus homosexuality was conceived as a contagious psychological illness that must be prevented "by restricting propaganda of homosexuality in the form of parades, pedagogy, and parenting" (Moss). Graeme Reid, the LGBT rights program director at Human Rights Watch, commented aptly that "Russia is trying very hard to make discrimination look respectable by calling it 'tradition,' but whatever term is used in the bill, it remains discrimination and a violation of the basic human rights of LGBT people" ("Russia: Drop Homophobic Law"). The law was approved by the Federation Council and promptly signed by President Putin (see "Zakonoproekt"), labelled the "czar of homophobia" by human rights campaigner Peter Tatchell, who has expressed concern that

under Putin's increasingly autocratic rule Russia is reverting to the statesanctioned homophobia of the Tsarist and Stalinist eras. The liberalizing period in the early 1990s, which led to the decriminalization of homosexuality in 1993, now just seems a distant aberration.

Although the law attempts to downplay its discriminatory language, Russian lawmakers tend to express their homophobic views shamelessly in public. For example, Vitalii Milonov, "one of the architects of the anti-gay laws," in his interview for The Independent, said that the majority in Russia "follow Christianity and, according to all surveys, 85 per cent of Russians support the law.... Tolerance tells us to understand the perverts. No one is born gay" (Morrison). 
The current backlash against LGBT human rights has also been rationalized by the Russian scholarly community. The political scientist Aleksei Mukhin, director general of Russia's Centre for Political Information, is known for demonizing Western support of Russian NGOs; a recent paper of his, titled ambitiously "Homo Politicus: Expert Analysis," in true conspiracy-theory style, predicts ominous consequences related to the implementation of human rights legislation. "The scenario moves from the first phase-recognition of tolerance for LGBT people, through the secondequal rights for LGBT and heterosexuals, to the third-recognition of gay domination" (Moss). The framework of this broad consensus, however, has been unsettled unexpectedly by the dissenting voice of Aleksandr Dugin. A political philosopher, professor of sociology at Moscow State University, ideologist of Neo-Eurasionism, and proponent of fascist thought, Dugin "has Putin's back in the emerging ideological conflict between Russia and the West" (Tolstoy and McCaffrey). In the foreword to his book, Gomoseksualizm na sluzhbe natsional'no-osvoboditel'nogo dvizheniia (Homosexuality in the Service of the National Liberation Movement), Dugin states that homosexuality can be either comprador or patriotic, and points out that the Russian state has made a fundamental mistake by refusing to accept, incorporate, and develop the homosexual discourse. According to Dugin, Russia must support patriotic homosexuality by juxtaposing it to European "sodomy." In doing so, Russia will strip Western propaganda of one more of its trump cards (Dugin). No matter whether this foreword is a mystification posted on the Internet or an authentic text, it factors smoothly into Dugin's ideological substantiation of his imaginary rivalry between Atlanticism and Eurasionism.

As some scholars assert, Russian political discourses have been employing concepts of femininity, masculinity, and homophobia (through enforced heteronormativity) to reflect Russia's "historical, economic, political, and cultural landscape, as well as the country's international position in the post-Cold War era" (Sperling 6). In this light, Russian politics have been reinforcing the masculinity of the regime's leadership by featuring Putin engaged relentlessly in a variety of macho acts: issuing his "official portrait" showing him stripped to the waist, fishing with foreign dignitaries in Siberia, riding a three-wheeler Harley Davidson with a Russian motorcycle gang, boarding a Mir I deep-water submarine, flying with baby cranes in a motorized hang glider (Foreman), celebrating his 63rd birthday by playing a hockey game with former NHLers and netting seven goals (Tomkiw), arm wrestling with his supporters from the Russian youth movement Nashi, sitting at the controls of a firefighting helicopter, operating a train, riding down a bobsled track, co-piloting a fighter jet, and shooting (Ihanus 115), thus demonstrating his strong-arm approach to politics. These images, operating as representations of power, manipulate the public 
imagination, inasmuch as they are staged as spectacles similar to actionist performances, wherein Putin's individual body politics and his political body image coincide. Moreover, facts that might compromise these glossed representations of a man of action's engagements in numerous pursuits, such as taking a flock of Siberian cranes back by plane because Putin's guidance on their migration path failed (Ihanus 117), or his fall during the hockey game mentioned above ("Vladimir Putin Takes a Tumble"), or his widely ridiculed, staged "discovery" of ancient Greek urns on the floor of the Black Sea near Ukraine "in the spur of his television heroics" (Parfitt), are dutifully overlooked or downplayed by the "slavishly devotional" Russian media. Instead, virtualized identities of an aging macho man defending the everlasting grandeur of Russia are branded, tailored, and paraded around the public sphere as an embodiment of hypermasculine powers. As Juhani Ihanus explains in his inquiry into Putin's machismo, hypermasculinity is often "connected to extremely traditional male gender roles with misogynist and homophobic convictions and stereotypes, 'othering' certain groups as hated, dangerous, and deserving of attack, and demanding respect for the aura of power and potential violence" (115). This aspect of Putin's political persona was evident during Russia's invasion of the Georgian region of South Ossetia in 2008. Putin, then prime minister, discussed his "plans" concerning Georgia with President Nicolas Sarkozy of France in blatantly sexualized terms, translating the violation of Georgia's sovereign borders by Russian troops into an image of the physical violation and emasculation of the Georgian president. After the respected French magazine Le Nouvel Observateur quoted this conversation, headlines in European newspapers read: "Vladimir Putin 'wanted to hang Georgian President Saakashvili by the balls"' (Times Online), "Vladimir Putin threatened to hang Georgia leader 'by the balls"' (The Telegraph), "Putin planned to topple the president of Georgia and 'hang him by the $\mathrm{b}^{* * * *}$, says Nicolas Sarkozy's chief adviser" (Daily Mail), and so on. Although Putin's press secretary described the publication in Le Nouvel Observateur as a "slur," it is not inconceivable that Putin, who is known for his "abrasive rhetoric," could have said this ("Putin Denies"). This is a telling representation of an obscenity of power that is abused.

A much mellower manifestation of Putin's unsettling conceptualization of contemporary political and economic situations in terms of sexual and gender roles (and their reassignment) is his response to a question about dropping oil prices at a press conference on the sidelines of the ASEM 2014 summit in Milan: "If a grandma had the genitals of a grandpa, she would be a grandpa" ("Italy: 'If a Grandma'”). In my opinion, such spontaneous responses reveal much more about Putin's outlook than political scientists' attempts to establish a comprehensive system of his political views by drawing on his official speeches, as they clearly point toward a rift between social meaning (sexual reference) and context (press conference at the 
international forum) in his social behaviour. I am further inclined to interpreted such sexually-loaded statements as symptomatic of Russian socio-political climate by drawing on the views of those scholars who study social behaviour and argue that the rigid state control over social institutions in Russia "leads to the spread of low-reflexive uses of the body at the higher registers of action" (Oleinik 755). In this light, we encounter here the transposing of unconscious or semiconscious actions-and their verbalization-from the private sphere of sexual pleasure to the public political domain (Oleinik 754-55), thus showcasing political technologies that appeal to "nether" regions of public reflexivity. In short, Putin is appealing to the basic instincts of his subjects and successfully triggering an anticipated response through an established rapport.

The mythology of sexual prowess and appetites, inviting admiration and desire, also factors into Putin's image as an embodiment of hypermasculinity. Discussing the constructed media persona of the Russian president as a glamorous, elite sexual icon, Helena Goscilo writes:

Macho, physically potent, and fearless "Putin" functions as an unattainable ideal for men and triggers a correspondingly prescribed "feminine" response from women, who, in diverse, often startling, cultural forms avow love and reverence for the politician as Superman. (4)

Thus, for his 58th birthday, Putin received an unusual gift, a calendar, made by twelve female journalism students at Moscow State University, each month featuring "one of the students posing in fancy underwear, with words of flattery printed beside her scantily clad image" ("Russian Students Create"). Fifty thousand copies of the calendar, called "Vladimir Vladimirovich, We Love You. Happy Birthday, Mr. Putin," went on sale in Moscow supermarkets ("Russian Students Make"). As if responding to this popular initiative and rendering his female subjects' exalted love, a Russian tabloid newspaper printed 200,000 copies of the 2016 calendar, called "The Whole Year with the Russian President" (Chance), in which Putin appears shirtless-again-among the expected twelve glamorous shots (Morgan). Such starry-eyed appreciation of Putin's sexual stardom by future female journalists, however, is far eclipsed by a tasteless, grotesque, and bizarre proposal allegedly put forward by the notorious chairwoman of Russia's Parliamentary Commission on Women's Affairs, Children, and Family, Ielena Mizulina. Associated with Russian legislation forbidding foreigners to adopt Russian children (known as the Dima Iakovlev Law), and a "key framer" of a law banning "propaganda of nontraditional sexual orientations among minors" (Lipman), Mizulina proposes to use Putin as a sperm donor to extend the greatness of Russia. Russian women who become pregnant through artificial insemination after receiving the Russian president's 
genetic material by mail will be eligible to receive special allowances from the government, and their children, all of them will be male without a doubt, will be raised in special military boarding schools, and eventually "form the military and political elite of the state" (Sanders). The proposal reflects an assortment of popular attitudes: that a male child is proof of the progenitor's sexual potency, that male offsprings are more valuable than female, and that women are just birthing machines. It is ironic that Mizulina, as an exponent of the Russian political establishment, instead of addressing declining life expectancy, the economic situation, poor health care, alcohol and drug abuse resulting in plummeting birth rates among Russians (see Epple et al.; Eberstadt; Litvinova, "Why Is Russia's Growth"), channels social demographic anxieties either into fighting homosexuality as a nonreproductive and therefore deviant sexual activity, or into creating a oneman, demiurgic sperm bank to solve Russia's problems.

According to Valerie Sperling, stressing Putin's machismo has become a legitimation strategy exercised by the Kremlin, as legitimacy is at stake in any political system (38). This intense energizing fantasy about an almighty "czar-father" figure reflects the ideas of masculinity that culturally synthesize Russian neo-imperialism. Although machismo is not the sole legitimation tactic employed by the Putin-centred regime-economic policy, family values, military might, and national patriotic pride also factor into evaluations of the right to rule-gender norms often come into play with regard to maintaining electoral support. This is especially true in the light of Russia's aggressive drives to assert its power in the former Soviet states (Sperling 3), which actions further promote the cultural conviction, rooted in political discourse and broadly diffused by the media, that the empire is the source and proof of Russia's glory, prestige, and global influence. The success of this tactical use of gender norms and sexualization of politics is guaranteed in a context where male dominance has become a pervasive cultural, psychological, and social phenomenon, and where misogyny and sexism are not contested by any cultural force.

This readily available sexist and misogynist Russian cultural idiom, actively engaged in the war between Russia and Ukraine, is superimposed over a traditional colonial homology between sexual and political dominance, with its ordering of masculine as superior to feminine. According to Ashis Nandy, this produced a "cultural consensus in which political and socio-economic dominance symbolized the dominance of men and masculinity over women and femininity" (4). It is thus highly predictable that Putin's performances of hypermasculinity demanded a Manichean construction of the Other, the enemy, the opponent. Meanwhile, President Petro Poroshenko of Ukraine is portrayed in the troll library not only as effeminate but also as a ridiculous transvestite dressed in lingerie. Here the male body, which is not usually interpreted in sexual terms, undergoes 
gendered conversion. There is a further aspect to Poroshenko's disempowerment because, as Valerie Steel argues in her book Fetish: Fashion, Sex and Power, "the power that patriarchal society has attributed to the phallus . . . is symbolized by phallic clothing" (184). By being forcibly stripped of his phallic mastery through a symbolic "disrobing," the Ukrainian president is placed in a submissive feminine role, based on the power differential implicit in traditional gender stereotypes. In addition to explicit gender bending and the positioning of the politician as a sex object and drag queen on display, the tableau implies sexual promiscuity and prostitution. Since Russian popular sexual ideology is a noxious mixture consisting of ideas of sexual sin, concepts of psychological inferiority, mob hysteria, and xenophobia (attitudes that are nourished by the relentless propaganda disseminated by the mass media), such "deviant" and "pathological" practices as transvestism occupy an even more scorned position than homosexuality in the sexual value system. Thus, Gayle Rubin in her groundbreaking essay "Thinking Sex" compares this kind of sexual morality with "ideologies of racism," as it "grants virtue to the dominant groups [representing essentialist heterosexuality], and relegates vice to the underprivileged" (283); those who exhibit the non-privileged aspects of sexuality and are deemed "other" or "unacceptable."

These pathologizing and othering strategies within the context of propaganda intentionally undermine masculinity and, by extension, the political legitimacy of the opponent, as one of the impacts of counterposing "good" (heteronormative) and "bad" ("straying" from compulsory heterosexuality) sexualized representations of the two presidents is that they frame such images within the realm of general, popular discourse as deficient, repulsive, and abnormal. Thus, President Poroshenko becomes most prominently identifiable via an unwanted, stigmatized, and sexualized identity. It is similarly symptomatic that Poroshenko, the cross-dresser, is eagerly awaiting a phone call from Putin's foremost adversary, President Obama. Implicating the American counterpart in this sexually deviant scenario renders the relationship between the two countries in a sex-formoney idiom, which is consistent with Russian views of the Ukrainian Maidan and Revolution of Dignity as sponsored by the evil American Gosdep (U.S. Department of State).

It is worth reiterating here that contemporary Russian public and political discourses are replete with suspicion and rejection of the West and Western values, primarily associating their pernicious influence with gender and sexual subversion. This tendency became particularly prominent in the months prior to Ukraine signing the European Union Association Agreement scheduled for November 2013 to formalize bilateral relations with the bloc. Russian propaganda, while attempting to lure Ukraine back to the Russian sphere of influence by convincing the country to join a Moscow-led custom's 
union, relentlessly played the homophobic and nationalist card, propped up by Russian Orthodox fundamentalism, and fomented anti-gay sentiments by, for example, equating Europe (Russian Evropa) with sexual "deviancy" by labelling it as Gayropa, European values as Eurogayan values, politics of tolerance as tolerastia (alluding to the Russian word pederastia, meaning "pederasty"), and representing Ukraine's entry into Europe via anal sex: " $V$ Evropu cherez zhopu" (To Europe through the ass) (Moss). Russian officials, such as Alexei Pushkov, chairman of the Duma's Foreign Affairs Committee, warned that an agreement with the European Union would mean that "pride parades will be held instead of Victory Day parades" in Kyiv (Feder). A new pro-Russian party, Ukrainian Choice (Ukrains'kyi vybir), created exclusively for lobbying against the strengthening of Ukraine's ties with the EU, stirred up "opposition to LGBT rights as part of the process" (Feder). Moreover, a bill similar to the Russian "homosexual propaganda" ban was introduced in the Ukrainian parliament (Verkhovna Rada) by Russian-leaning lawmakers (who unfailingly tried to follow the Russian lead in their legislative initiatives). The bill ultimately stalled, despite the fact that it was cosponsored by various parliamentary factions, thus unprecedentedly having united Ukraine's warring parties. In December 2013, following President Viktor Ianukovych's unilateral decision to defer the signing of the Agreement, Prime Minister Mykola Azarov, in keeping with bigoted Russian propaganda clichés, made ridiculous public statements on several occasions to support his claim that the Agreement was not the way for Ukraine because in order to "obtain a visa free regime with the European Union, Ukraine should legalize same-sex marriages" ("Head of the EU Mission"), making it sound as though it were the main prerequisite for the Association with the European Union.

It is noteworthy, though, that after the Russian offensive against Ukraine started, pro-Russian organizations disappeared from Ukrainian public spaces, a fact "often explained by Russia ceasing to fund them"; Ukrainian Choice (Ukrains'kyi vybir), together with another pro-Russian organization, People's Council (Narodnyi Sobor), relocated to the so-called Donetsk and Luhansk "people's republics"; street protests by the "defenders of traditional values" suddenly stopped; articles about the terrors of "Euro-Sodom" vanished; and the "most visible opponents of the "propaganda of homosexuality' left for Russia" (Teteriuk).

However, not unlike in Russia, negative social attitudes toward homosexuality remain widespread in Ukraine. For example, according to the 2013 GFK Ukraine poll, almost 80\% of respondents opposed any sexual relations between people of the same sex, and the Ukrainian Gay Alliance and Ukrainian State Sociological Institute poll indicated that 63\% categorized homosexuality as a "perversion" and a "mental disease" (Kenarov). However, if in Russia, as stated earlier, negative attitudes are on 
the rise, some slow changes occur in Ukraine. Since the pro-Western government came to power after the 2013-14 Maidan, "Ukrainian authorities have increased their support for LGBT" (Williams and Zinets), and, in November 2015, Ukrainian lawmakers passed a workplace antidiscrimination amendment to the Labour Code that is inclusive of sexual orientation ("Verkhovna Rada"). In addition, the March of Equality, organized by LGBT and human rights activists in Kyiv in June 2016, "passed off largely without incident" (Williams and Zinets) as compared to the previous year when the rally was marred by violence ("Ukraine: Homophobic Violence"). Since the issue of homosexuality is a convoluted one for both target (domestic and foreign) audiences, it has been strategically used as a loaded and dangerous weapon in the Russian propaganda campaign. On the one hand, being relentlessly replicated, it has been conducive to igniting anti-Ukrainian sentiments in Russia by relegating Ukrainians to the status of deviant abnormality and mental deficiency. On the other hand, among Ukrainian citizens, who are still consuming Russian media products, it has been used to delegitimize both Ukraine's European aspirations and the newly elected post-Maidan government's initiatives, thus attempting to swing public opinion toward pro-Russian attitudes and in favour of closer ties with Russia. In the "larger geopolitical confrontation" between Russia and Western liberal democracies, the Russian Federation used the ideology of "traditional values," which primarily capitalized on multiple phobias, "to ensure that Ukraine remained within its sphere of interests" (Teteriuk). Nevertheless, recent and feasible shifts, albeit slight, in the political discourses on LGBT rights in Ukraine demonstrate that the drive behind this propaganda device has already lost its momentum, and the results are not as effective as expected for non-Russian audiences.

While the incessant manipulation of gendered, essentialist, and sexualized discourses (both verbal and visual) in the Russo-Ukrainian war to devalue opponents shapes, reflects, and reinforces the valorization of homophobia and machismo, thus recruiting nationwide support in Russia, it is also symptomatic of what has been termed by numerous commentators as Russia's perpetual identity crisis (see, for example, Franklin and Widdis). Hence, as Anastasia Likhacheva and others suggest, the current conflict represents

a consequence of the crisis of national identity in Russia during the postSoviet period. And the ongoing crisis clearly reflects that unclear social, political, and national identities allow some stakeholders to substitute an objective stimulus for sustainable cooperation . . . by negative propaganda. (1)

On a side note: it is ironic that Russia's major hypermasculine "stakeholder" exhibits behaviours characteristic of macho, hegemonic masculinity-the 
"lack or minimizing of contacts and negotiations for constructive mutual understanding" (Ihanus 115) - thus leading Russia, since its forcible annexation of the Crimea, to embark "on a downhill journey, both domestically and internationally, which is clearly threatening its sustainability, capacity for economic growth, and peaceful development" (Barabashin). Being affected, even if only partially, by phantom limb syndrome, that is, the failure to reconcile to the loss of what Ewa Thompson terms the "inner empire," the Russian political elites seem "unable to grant to Russia's neighbors-Ukrainians, Balts, Central Asians, Georgians, Chechens, and others - the right to view history in their own way and to proclaim their separate identities" (Thompson 192) and, by extension, to choose their own future. What seemed, in the late 1990s, to be a postimperium Russia's reconciliation with its diminished global role has turned into a "comeback of imperial reflex" to subdue and colonize neighbouring states (Van Herpen, Putin's Wars 2). And what is handier, then, than resorting to the tired imperial tactics of vilifying othering, both in terms of asserting Russia's own identity and justifying aggression? And what is more appealing in a country whose president regularly employs genital imagery in his public speeches than resorting to sexualized political discourse, which popular audiences in Russia seem to find highly compelling? It would appear that in the Russian "geopolitical" imagination, brutal, senseless, and paranoid warfare in Ukraine, nuclear posturing in the Baltics, and atrocities in Syria are constructed as a competition between virile Russia and the impotent, evil West.

\section{Works Cited}

"Actionism." Tate. Glossary of Art Terms, http://www.tate.org.uk/learn/onlineresources/glossary/a/actionism. Accessed 17 Feb. 2017.

Allawala, Katie. "Putin's Russia: Down But Not Out, Part 1." Foreign Affairs, 18 Apr. 2016, https://www.foreignaffairs.com/audios/2016-04-18/putins-russiadown-not-out-part-1. Accessed 17 Feb. 2017.

Baer, Brian James. Translation and the Making of Modern Russian Literature. Bloomsbury Academic, 2016.

Barbashin, Anton. "Why Do We Still Believe in Putin's 'Strategy'?" Intersection: Russia/Europe/World, 17 March 2016, http://intersectionproject.eu/article/politics/why-do-we-still-believe-putinsstrategy. Accessed 17 Feb. 2017.

Baudrillard, Jean. "Simulacra and Simulation." Jean Baudrillard. Selected Writings, edited by Mark Poster, Stanford UP, 1988, pp. 166-84.

Beynon, John. Masculinities and Culture. Open UP, 2002.

Bhabha, Homi K. The Location of Culture. Routledge, 1994. 
Chance, Matthew. "Vladimir Putin's 2016 Calendar: Spend the Year with Russia's President." CNN, 29 Dec. http://www.cnn.com/2015/12/28/europe/vladimir-putin-calendar-2016/. Accessed 17 Feb. 2017.

Dugin, A. “'K voprosu o patrioticheskom gomoseksualizme.' Predislovie k knige 'Gomoseksualizm na sluzhbe natsional'no-osvoboditel'nogo dvizheniia.'” Rufabula, 21 May 2016, https://rufabula.com/author/alexander-blog/1214. Accessed 17 Feb. 2017.

Eberstadt, Nicholas. "Drunken Nation: Russian Depopulation Bomb." World Affairs Journal, Spring 2009, http://www.worldaffairsjournal.org/article/drunkennation-russia's-depopulation-bomb. Accessed 17 Feb. 2017.

Epple, Nikolai, et al. "Russian Health Care Is Dying a Slow Death." The Moscow Times, 16 Apr. 2015, http://www.themoscowtimes.com/opinion/article/russianhealth-care-is-dying-a-slow-death/519253.html>. Accessed 17 Feb. 2017.

Feder, J. Lester. "The Russian Plot to Take Back Eastern Europe at the Expense of Gay Rights." BuzzFeed News, 9 Nov. https://www.buzzfeed.com/lesterfeder/russia-exports-homosexualpropaganda-law-in-effort-to-fight?utm term=.siR1PKzYp - . .teg7M6Zbm. Accessed 17 Feb. 2017

Foreman, Katya. "Vladimir Putin's Alpha Male Apparel." BBC Culture, 21 Oct. 2014, http://www.bbc.com/culture/story/20130730-vladimir-putin-action-man. Accessed 17 Feb. 2017.

Foucault, Michel. Discipline and Punish: The Birth of the Prison. Translated by Alan Sheridan, Penguin, 1977.

Fout, John C. "Sexual Politics in Wilhelmine Germany: The Male Gender Crisis, Moral Purity, and Homophobia." Forbidden History: The State, Society, and the Regulation of Sexuality in Modern Europe, edited by John C. Fout, U of Chicago P, 1992, pp. 259-92.

Franklin, Simon, and Emma Widdis, editors. National Identity in Russian Culture: An Introduction. Cambridge UP, 2004.

Freitag, Jason. Serving Empire, Serving Nation: James Tod and the Rajputs of Rajastan. Brill, 2009.

"Geteroseksual'nost'."

Russian

Wikipedia, https://ru.wikipedia.org/wiki/Гетеросексуальность. Accessed 17 Feb. 2017.

Goscilo, Helena, editor. Putin as Celebrity and Cultural Icon. Routledge, 2013.

Greenberg, David F. The Construction of Homosexuality. U of Chicago P, 1988.

"Head of the EU Mission: Mykola Azarov Statement on Same-Sex Marriages Has Nothing to Do with the Reality." Gay Alliance Ukraine, 27 Dec. 2013, http://upogau.org/eng/inform/uanews/worldnews_619.html. Accessed 17 Feb. 2017.

Ihanus, Juhani. “Putin's Macho Pose: On Masculinity and Psychopolitics.” Journal of Psychohistory, vol. 42, no. 2, 2014, pp. 110-29.

"Italy: 'If a Grandma Had the Genitals of a Grandpa'-Putin." LiveLeak, 17 Oct. 2014, http://www.liveleak.com/view?i=0e9_1413576795\&comments=1. Accessed 17 Feb. 2017. 
Kenarov, Dimiter. “Dashed Hopes in Gay Ukraine.” Foreign Policy, 15 Jan. 2015, http://foreignpolicy.com/2015/01/19/dashed-hopes-in-gay-ukraine-maidanrussia/. Accessed 17 Feb. 2017.

Komitet Gosudarstvennoi Dumy po Voprosam Sem'i, Zhenshchin i Detei. 6 June 2013, http://www.komitet2-6.km.duma.gov.ru/site.xp/052057124053056057.html. Accessed 17 Feb. 2017.

Kondakov, Alexander. "The Silenced Citizens of Russia: Exclusion of NonHeterosexual Subjects from Right-Based Citizenship." Social \& Legal Studies, vol. 23, no. 2, 2014, pp. 151-74.

Kon, Igor. "Sexual Minorities." Sex and Russian Society, edited by Igor Kon and James Riordan, Indiana UP, 1993, pp. 89-115.

Krishnaswamy, Revathi. Effeminism: The Economy of Colonial Desire. U of Michigan P, 1998.

Likhacheva, A., et al. "Post-Soviet Russian Identity and Its Influence on EuropeanRussian Relations." European Journal of Futures Research, vol. 3, no. 4, 2015, pp. 1-8. Springer, doi: 10.1007/s40309-015-0062-0.

Lipman, Masha. “The Battle over Russia's Anti-Gay Law.” The New Yorker, 10 Aug. 2013, http://www.newyorker.com/news/news-desk/the-battle-over-russiasanti-gay-law. Accessed 17 Feb. 2017.

Litvinova, Daria. "Poll Shows Russian Attitudes to Gay People Are Worse Than Decade Ago." The Moscow Times, 10 July 2015, http://www.themoscowtimes.com/news/article/poll-shows-russian-attitudesto-gay-people-are-worse-than-decade-ago/525429.html. Accessed 17 Feb. 2017.

---. "Why Is Russia's Growth in Life Expectancy Slowing?" The Moscow Times, 30 Aug. 2015, http://www.themoscowtimes.com/news/article/why-is-russias-growthin-life-expectancy-slowing/529029.html. Accessed 17 Feb. 2017.

McClintock, Anne. Imperial Leather: Race, Gender and Sexuality in the Colonial Contest. Routledge, 1995.

Mitchell, Peta. Cartographic Strategies of Postmodernity: The Figure of the Map in Contemporary Theory and Fiction. Routledge, 2008.

Morgan, Lee. "Vladimir Putin Goes Shirtless Again for New 2016 Calendar." The Huffington Post, 26 Dec. 2015, http://www.huffingtonpost.com/entry/vladimirputin-calendar-2016 us 567e5d2fe4b0b958f6597836. Accessed 17 Feb. 2017.

Morrison, Sarah. "Vladimir Putin's Attack on Homosexuality Is Shattering the Lives of Russians." The Independent, 12 Jan. 2014, http://www.independent.co.uk/news/world/europe/vladimir-putin-s-attackon-homosexuality-is-shattering-the-lives-of-russians-9054660.html. Accessed 17 Feb. 2017.

Moss, Kevin. "Russian Occidentalism: Gayropa and Russia's Traditional Values." Paper presented at the European Conference on Politics and Gender. University of Uppsala, Sweden. 11-13 June 2015, http://ecpr.eu/Events/PaperDetails.aspx?PaperID=23231\&EventID=100. Accessed 17 Feb. 2017.

Motyl, Alexander J. "Deconstructing Putin on Ukraine." World Affairs, 11 Sept. 2013, http://www.worldaffairsjournal.org/blog/alexander-j-motyl/deconstructingputin-ukraine. Accessed 17 Feb. 2017. 
Nandy, Ashis. The Intimate Enemy: Loss and Recovery of the Self Under Colonialism. Oxford UP, 1983.

Oleinik, Anton. "Uses and Abuses of Sexuality in Social Interactions: Empirical Evidence from Russia." Europe-Asia Studies, vol. 62, no. 5, 2010, pp. 749-78.

Omel'chenko, Elena, and Al'bina Garifzianova. "Skinheads As Defenders of Russia? Power versus Friendship in Xenophobic Youth Subcultures." Subcultures and New Religious Movements in Russia and East-Central Europe, edited by George McKay et al., Peter Lang, 2009, pp. 33-60.

Parfitt, Tom. "Vladimir Putin's Greek Urns Claim Earns Ridicule." The Guardian, 12 Aug. 2011, https://www.theguardian.com/world/2011/aug/12/vladimirputin-greek-urns-ridicule. Accessed 17 Feb. 2017.

Porter, Tom. "LGBT Rights in Russia: Majority of Russians Want to 'Liquidise' or Ostracise Homosexuals." International Business Times, 12 Oct. 2015, http://www.ibtimes.co.uk/lgbt-rights-russia-majority-russians-want-liquidiseostracise-homosexuals-1523639. Accessed 17 Feb. 2017.

Pratt, Jonathan Brooks. "The Body Politic: How Pyotr Pavlensky's Performance Art Is Breaking the Mould." The Calvert Journal, 13 Nov. 2014, http://calvertjournal.com/comment/show/3365/pyotr-pavlensky-protest- artliving-pain-sculpture. Accessed 17 Feb. 2017.

"Putin Denies Crude 'Hanging' Jibe." BBC News, 14 Nov. 2008, http://news.bbc.co.uk/2/hi/7729147.stm. Accessed 17 Feb. 2017.

Riabov, Oleg, and Tatiana Riabova. "The Decline of Gayropa? How Russia Intends to Save the World." Eurozine, 5 Feb. 2014, http://www.eurozine.com/the-declineof-gayropa/. Accessed 17 Feb. 2017.

Rubin, Gayle. "Thinking Sex: Notes for a Radical Theory of the Politics of Sexuality." Pleasure and Danger: Exploring Female Sexuality, edited by Carole Vance, Routledge, 1984, pp. 267-319.

Russian Criminal Tattoo Encyclopaedia. Steidl/Fuel, 2003.

"Russia: Drop Homophobic Law, Investigate Murders, Stop Prosecuting LGBT Groups." Human Rights Watch, 11 June 2013, http://www.hrw.org/news/2013/06/10/russia-drop-homophobic-law. Accessed 17 Feb. 2017.

"Russian Students Create Erotic Calendar for Putin." The Huffington Post, 7 Oct. 2010, http://www.huffingtonpost.com/2010/10/07/russian-students-createe n 754047.html. Accessed 17 Feb. 2017.

"Russian Students Make a Racy Calendar for Putin." The Telegraph, 6 Oct. 2010, http://www.telegraph.co.uk/news/worldnews/europe/russia/8047282/Russi an-students-make-racy-birthday-calendar-for-Putin.html. Accessed 17 Feb. 2017.

Sands, Kathleen M. "Homosexuality, Religion, and the Law." Homosexuality and Religion: An Encyclopedia, edited by Jeffrey S. Siker, Greenwood P, 2007.

Sanders, Kevin. "Russian Lawmaker Proposes Mailing Putin Sperm to Impregnate Russian Women." The Observer, 11 June 2014, http://observer.com/2014/11/russian-lawmaker-proposes-mailing-putinsperm-to-impregnate-russian-women/. Accessed 17 Feb. 2017. 
Schreck, Carl. "Russian Trolls' Vast Library of Insulting Images." Radio Free Europe, 4 April 2015, http://www.rferl.org/content/russian-trolls-vast-insult-cartoondatabase/26938435.html. Accessed 17 Feb. 2017.

Sneider, Noah. "Body Politics." 1843 Magazine, June-July 2016, https://www.1843magazine.com/features/body-politics. Accessed 17 Feb. 2017.

Sperling, Valerie. Sex, Politics, and Putin: Political Legitimacy in Russia. Oxford UP, 2015.

Stähle, Hanna. "Between Homophobia and Gay Lobby: The Russian Orthodox Church and Its Relationship to Homosexuality in Online Discussions." Digital Orthodoxy in the Post-Soviet World: The Russian Orthodox Church and Web 2.0, edited by Mikhail Suslov, Ibiderm-Verlag, 2015, pp. 161-94.

Steel, Valerie. Fetish: Fashion, Sex and Power. Oxford UP, 1996.

Tatchell, Peter G. "Vladimir Putin, The Czar of Homophobia." Huffington Post, 20 July 2013, http://www.huffingtonpost.co.uk/peter-g-tatchell/homophobia-russiavladimir-putin_b_3544610.html. Accessed 17 Feb. 2017.

Teteriuk, Maria. "A Litmus Test for Post-Maidan Democracy: Anti-Discrimination Legislation." Eurozine, 22 Feb. 2016, http://www.eurozine.com/articles/201602-22-teteriuk-en.html. Accessed 17 Feb. 2017.

"The Global Divide on Homosexuality: Greater Acceptance in More Secular and Affluent Countries." Pew Research: Global Attitudes, 4 June 2013, http://www.pewglobal.org/2013/06/04/the-global-divide-on-homosexuality/. Accessed 17 Feb. 2017.

Thompson, Ewa M. Imperial Knowledge: Russian Literature and Colonialism. Greenwood P, 2000.

Tolstoy, Andrey, and Edmund McCaffrey. "Mind Games: Alexander Dugin and Russia's War of Ideas." World Affairs Journal, Mar.-Apr. 2015, http://www.worldaffairsjournal.org/article/mind-games-alexander-dugin-andrussia's-war-ideas. Accessed 17 Feb. 2017.

Tomkiw, Lydia. "Vladimir Putin's Birthday Hockey Game: Airstrikes in Syria Continue As Russian President Celebrates His 63rd." International Business Times, 7 Oct. 2015, http://www.ibtimes.com/vladimir-putin-birthday-hockey-gameairstrikes-syria-continue-russian-president-2131049. Accessed 17 Feb. 2017.

"Ukraine: Homophobic Violence Mars Gay Pride Rally in Kyiv." Amnesty International, 6 June 2015, https://www.amnesty.org/en/latest/news/2015/06/homophobicviolence-mars-gay-pride-rally-in-kyiv/. Accessed 17 Feb. 2017.

Van Herpen, Marcel H. Putin's Propaganda Machine: Soft Power and Russian Foreign Policy. Rowman \& Littlefield, 2016.

---. Putin's Wars: The Rise of Russia's New Imperialism. 2nd ed., Rowman \& Littlefield, 2016.

"Verkhovna Rada Ukrainy ukhvalyla zakon 'Pro vnesennia zmin do Kodeksu zakoniv pro pratsiu Ukrainy shchodo harmonizatsii zakonodavstva u sferi zapobihannia ta protydii dyskryminatsii iz pravom Ievropeis'koho Soiuzu." Verkhovna Rada Ukrainy, 12 Nov. 2015, http://rada.gov.ua/news/Novyny/118982.html. Accessed 17 Feb. 2017.

"Vladimir Putin Takes a Tumble During Ice Hockey Game-Video." The Guardian, 11 May 
https://www.theguardian.com/world/video/2016/may/11/vladimir-putintumble-ice-hockey-video. Accessed 17 Feb. 2017.

VSHtabe.Rf. http://вштабе.pф/. Accessed 17 Feb. 2017.

Walker, Shaun. "'Salutin' Putin: Inside a Russian Troll House." The Guardian, 2 Apr. 2015, https://www.theguardian.com/world/2015/apr/02/putin-kremlininside-russian-troll-house?CMP=share btn_fb. Accessed 17 Feb. 2017.

Wandor, Michelene. Post-War British Drama: Looking Back in Gender. Routledge, 2001.

Williams, Matthias, and Natalie Zinets. "Praise from West After Mostly Peaceful Kiev Pride Match." Reuters, 12 June 2016, http://www.reuters.com/article/usukraine-pride-parade-idUSKCNOYYOFD. Accessed 17 Feb. 2017.

"Zakonoproekt 44554-6. 0 vnesenii izmenenii v stat'iu 5 Federal'nogo zakona '0 zashchite detei ot informatsii, prichiniaiushchei vred ikh zdorov'iu i razvitiiu' i otdel'nye zakonodatel'nye akty Rossiiskoi Federatsii v tseliakh zashchity detei ot informatsii, propagandiruiushchei otritsanie traditsionnykh semeinykh tsennostei." Federal'noe Sobranie Rossiiskoi Federatsii. Gosudarstvennaia Duma. Ofitsial'nyi sait, http://asozd2.duma.gov.ru/main.nsf/\%28SpravkaNew\%29?0penAgent\&RN=4 4554-6\&02. Accessed 17 Feb. 2017. 